\title{
Present Situation Problems and Countermeasures of Rural Endowment Insurance System in China
}

\author{
Yuansong Xie \\ Jiangxi Technical College of Manufacturing 330095, China
}

Keywords: Rural endowment insurance system; present situation; problems; countermeasures

\begin{abstract}
Since the 80s of last century, the rural old-age insurance has experienced a tortuous development process. During the exploration period, the rural old-age insurance system is obviously characterized by low level 、non uniform and regional characteristics. China's current rural endowment insurance system, there are many problems. The construction of China's rural endowment insurance system must be based on the reality of China, needs bring forth new ideas in system.
\end{abstract}

\section{Introduction}

Building a socialist harmonious society, it can not be separated from the rural areas and farmers, it can not be separated from the rural old-age insurance system. With the rapid increase of the elderly population in rural areas, the pressure on the rural areas has been increasing rapidly in recent years. The rural old-age problem has become an important concerning problem, it cannot be ignored. As a guarantee for the sustainable development of China's rural old-age insurance system, in which state, whether it is in line with the objective needs of the reality, to solve the problem, after many research and practice. The author hopes that through the discussion of this article, it gives a preliminary answer, and hope to improve the rural endowment insurance system of our country.

\section{The present situation of rural endowment insurance system : low level and not uniform}

In the 80s of last century, China began to explore the establishment of rural endowment insurance system. On the basis of summing up experiences and opinions, the Ministry of civil affairs of the people's Republic of China promulgated the basic scheme of rural social endowment insurance level in 1992.

The introduction of the basic program has promoted the development of the rural old-age insurance. By the end of 20th, a total of 31 provinces and municipalities directly under the central government to carry out the work of rural social endowment insurance. However, the basic program is not a law, it is only a policy arrangement, the level is low, lack of authority, only a guide, not mandatory. There are some problems in the work of rural endowment insurance, due to the lack of difficulties and the defects of the system itself. The State Council pointed out in the relevant documents, at present, China's rural areas do not have the conditions of universal social insurance. The original implementation of the Civil Affairs Department of the village social endowment insurance, to straighten out, stop accepting new business, it can be gradually transformed into commercial insurance. After that, China's rural endowment insurance is shrinking.

In recent years, with the increasing attention to the issue of agriculture v rural areas and farmers, only in some areas to carry out a new round of rural old-age insurance. The new trend of rural 
endowment insurance is coming.

\section{Need to solve the problems: multiple constraints}

There are many problems in the primary stage of China's rural endowment insurance system. These problems exist for a long time, which restricts the development of rural endowment insurance of our country. Combined with the debate in the academic circles, the author sums up the following questions:

Pattern dispute. Rural endowment insurance should adopt the integration or different patterns of urban and rural. It is well known, from the beginning of the last century in 50s, based on various reasons, China has adopted the dual household registration system. In our country, the household register is free of its own population information function, and it is the important basis to define people's identity, assign rights, interests and obligations. The dual household registration system makes the basic rural population excluded from the social security system, which is in accordance with the plan to carry out the so-called rural endowment insurance, endowment insurance is not real endowment system, it maybe called pension savings, because in most cases the government does not invest. Starting from the perspective of social justice, scholars have called for the integration of urban and rural old-age security model; but the administrative departments comrades think, development of urban and rural old-age security model is too ideal, take the different urban and rural endowment insurance mode is appropriate.

How to undertake the responsibility of government in the rural endowment insurance. The practice of rural endowment insurance of our country has proved that the role of government is not clear, and the lack of function is an important factor restricting its development. Although the provisions of the plan of rural endowment insurance fund raising the implementation of national, collective and individual combination principle, but in the actual implementation, the state of rural endowment insurance has not invested, collective responsibility are seldom carried out. The interest mechanism of rural endowment insurance neither stimulate the insured, actually it cannot reach the purpose of pension.

Rural endowment insurance should adopt the unified standard of the country or should vary from place to place. China is a unitary state, which is reflected in the legal field, and the reasonable logic is the formation of a unified national legal rules. Starting from this principle, the old-age insurance system should also be unified, should not vary from place to place. However, China's vast territory, the development of different regions of the rural endowment insurance conditions are different, demanding a unified national standards may be too stiff. However, if allowed each administers in his own way will cause over the lack of coordination, while pension standards vary among the results. A slight flow of population, it will lead to the problem of pension insurance docking between regions. It is an unavoidably problem that the rural endowment insurance should be adopt the unified standard of the country or should vary from place to place. For a long period of time, this problem has been plagued by policy makers, it has become an important reason for China's rural old-age insurance policy wavering.

How to ensure social equity. Rural pension insurance scheme to take voluntary principle. From the practical point of view, the current old-age insurance in rural areas, mainly in the economically developed rural areas, to participate in rural old-age insurance is almost more affluent farmers. Even if this part of the people do not participate in pension insurance, pension is not a problem, the future pension is facing the pressure of farmers in underdeveloped areas and the poor farmers can not afford the premium. This kind of endowment insurance system, which is rich and poor, does not solve the fundamental problem of rural pension in the future. This insurance system cannot 
guarantee a serious tendency of poverty, the problem of the elderly population is not a fundamental solution to the problem, which is placed in the middle of a very realistic problem of rural pension.

How to manage the rural endowment insurance fund, avoid the risk and realize the added value. The rural endowment insurance funds involves hundreds of millions of Rural Elderly Security really can be achieved or not. The current rural endowment insurance fund management level is low, the value difficult to misappropriation and other issues. These problems exist for a long time, it is bound to fundamentally shake the foundation of the rural old-age insurance, endangering the development of rural endowment insurance. How to strengthen the management and avoid the risk of the rural endowment insurance fund has been a lingering problem.

\section{The feasible way of constructing the rural endowment insurance system with Chinese characteristics: based on the reality and institutional Innovation}

Compared with other countries, China's rural areas are unique in the world. To carry out the rural endowment insurance, we must rely on financial resources to meet the requirements of social security and social harmony, and to adapt the social structure of the country, the development path and the level of economic development. Rural old-age insurance can not be completely transplanted from other countries, both in a country's successful experience, China's rural endowment insurance is only a reference, but not the overall fit. Based on the above facts, the Chinese rural endowment insurance must based on the reality and make institutional Innovation.

In the choice of the rural old-age insurance model, unified national embodies the idea of equality, it is to resolve the differences between urban and rural areas, and the inevitable requirement of the realization of legal equality, it is the pursuit of the goal of rural endowment insurance. The breaking of the dual structure of urban and rural division. However, in today's China, the existence of dual household registration is a fact. Dual household registration system implemented more than half a century of time in China, its impact on the Chinese society not only extremely profound and short time to eliminate this week, in the pursuit of the integration of urban and rural endowment insurance mode, a significant departure from the truth, highlighting the utopia elements. Not only will cause avoidable the risk, and because do not have the real conditions, it will delay and can not be implemented, waste valuable time. From abroad, it is not all countries are consistent with the pension insurance in urban and rural areas. The world has 162 countries and regions to implement the implementation of the social endowment insurance system, but only 70 countries and regions contain rural areas. From the operational point of view, at this stage of the rural endowment insurance is still in the division of urban and rural mode is appropriate. On the one hand, try to avoid new contradiction between urban and rural areas, on the other hand, must set aside the necessary space for the docking of two model.

Accurate government orientation is the key to the implementation of rural endowment insurance. The development of social security is an important public management function of the government. In the implementation of rural endowment insurance in our country, in the pension fund to raise funds, government funds play an important role. The construction of China's new rural endowment insurance is inseparable from the role of government.

Under the premise of feasibility, the pursuit of national unity system should be the goal of rural endowment insurance, which is also an important manifestation of regional fairness. The problem is that China gets vast rural areas, the situation varies widely in different regions. The eastern part of the government finances are relatively abundant, relatively well-off farmers, raising pension funds for the government and the insured person may not be difficult. But in the western region, many local financial difficulties, some local farmers even have a basic survival difficulties, asking them to 
come up with some of the money for future life which is unrealistic. At present many deep system failed to straighten out, in the short term is unlikely to allow the country to straighten out the situation, according to the actual local actively explore the rural endowment insurance for the region, providing multiple fan constructing the rural old-age insurance for the future can be unified, accumulated positive and negative experience, it is the only feasible way. But in the practice, the central government must strengthen guidance and coordination, in a unified under the principle of not allowing all of its own, lacking spirit of cooperation, must be unified for the system of reserved space, reduce the cost of future docking system.

On ensuring social equity. Endowment insurance is social insurance, it is not commercial insurance. Social insurance is compulsory, which is established and enforced by the state legislation. Both the insured and the insured have to take part in it unconditionally. This is also the reason why some scholars advocate the establishment of compulsory participation in the social endowment insurance system. But at this stage of rural endowment insurance, an unavoidable proposition is how to reduce the contradictions, strive for the support of farmers. Rigid adherence to certain characteristics of social insurance, rural pension insurance will only be unable to implement the situation. From this level, it is appropriate to change the mandatory nature of traditional social insurance. At the present stage, it is more feasible to adopt the voluntary way of rural endowment insurance. Under the principle of voluntary pension insurance in rural areas, it is possible to have the rich farmers to insure, poor farmers are unwilling or unable to insure, and therefore can not enjoy the benefits of insurance. The author believes that this problem can be solved through the interest mechanism. China's rural endowment insurance should be based on the government and individuals as payment subject; encourage qualified investment in farmers' collective economic organizations, a portion of the money under the condition of government subsidies.

\section{Conclusion}

The rural social insurance system of our country is complex and diverse, it is necessary to make reasonable arrangements on the basis of comprehensive analysis, according to the situation of our country and learn from good practices.

\section{References:}

[1] Ciao-Ding L I, An-Gang B U. Present situation and countermeasures of rural collective endowment management in Changsha Nanjing[J]. Fijian Agricultural Science \& Technology, 2014, 45(4):80-83.

[2] Yang W S, Ding-Ling H U. Analyst the Present Situation of China's Rural Endowment Insurance and Research the Countermeasures[J]. Science Technology \& Industry, 2008.

[3] Chang M. The Problems and Countermeasures of Chinese Rural Social Endowment Insurance[J]. Journal of Social Work, 2008.

[4] Bin C. The Construction of the Ruralcommunity Endowmentservice Present Situation and Countermeasure Analysis[J]. Journal of Anyang Institute of Technology, 2014. 